\title{
ANALISIS EKO-EFISIENSI DAUR ULANG AIR LIMBAH DI PT. CHEMCO HARAPAN NUSANTARA
}

\author{
Nisa Nurhidayanti ${ }^{1}$, Akhmad Khawari ${ }^{2}$ \\ ${ }_{1,2}^{1}$ Universitas Pelita Bangsa \\ ${ }^{1}$ nisa.kimia@pelitabangsa.ac.id \\ ${ }^{2}$ akhmadkhawari@yahoo.com
}

\begin{abstract}
Abstrak - PT. Chemco Harapan Nusantara (PT CHN) membutuhkan air bersih dalam jumlah besar untuk digunakan sebagai air proses dalam kegiatan proses produksi. Adapun total kebutuhan air bersih untuk semua proses produksi yaitu sebanyak $10.450 \mathrm{~m}^{3}$ / bulan. PT CHN dapat menghasilkan produk yang bernilai jual dari penggunaan air bersih tersebut. Di samping itu juga menghasilkan air limbah yang dapat mencemari lingkungan. Tujuan dari penelitian ini adalah untuk menerapkan metode daur ulang air limbah pada PT CHN sehingga dapat mengurangi dampak buruk bagi lingkungan akibat pembuangan air limbah dan menghasilkan penghematan secara ekonomi terutama pada saat Pandemi Covid19 ini. Penerapan dari metode tersebut dilakukan dengan cara mengolah air limbah di dalam instalasi pengolahan air limbah, kemudian mengolah kembali air tersebut di dalam instalasi pengolahan air bersih. Air olahan yang diperoleh kemudian di distribusikan ke masing-masing proses produksi pemakai air bersih. Metode yang digunakan dalam penelitian ini adalah dengan wawancara dan survei secara langsung di lokasi kemudian menganalisis hasil penelitian dengan teknik analisa data coding, entering, cleaning, display dan analyzing. Berdasarkan hasil penelitian menunjukkan bahwa penerapan metode daur ulang air limbah mampu mengubah seluruh air limbah menjadi air bersih yang dapat digunakan untuk proses produksi , sehingga tidak mencemari lingkungan. Hal tersebut terbukti bahwa pada prosesnya seluruh air limbah dimasukkan ke dalam instalasi pengolahan air limbah yang kemudian diolah lagi di WTP dan air hasil olahan dari WTP tersebut digunakan kembali sebagai process water. Penerapan metode daur ulang air limbah yang dilakukan oleh PT CHN juga dapat menguntungkan secara ekonomi yaitu dengan dapat mengurangi pemakaian air WTP Jababeka sebesar 77,5 \%, sehingga mampu menghemat biaya pengeluaran pembelian air sebesar Rp 99.187.652 /bulan.
\end{abstract}

Kata kunci: efektivitas, efisiensi, daur ulang, lingkungan, ekonomi

Abstract - PT. Chemco Harapan Nusantara (PT CHN) requires large amounts of clean water to be used as process water in production process activities. The total need for clean water for all production processes is $10.450 \mathrm{~m}^{3} /$ month. PT CHN can produce products of value from the use of clean water. Besides that, it also produces waste water which can pollute the environment. The purpose of this research is to apply the wastewater recycling method at PT CHN so as to reduce adverse environmental effects due to waste water disposal and generate economic savings, especially during the Covid Pandemic19. The application of this method is done by treating wastewater in a wastewater treatment plant, then reprocessing the water in a clean water treatment plant. The processed water obtained is then distributed to each of the clean water user production processes. The method used in this study is to interview and survey directly on site and then analyze the results of research with data analysis techniques coding, entering, cleaning, display and analyzing. Based on the results of the study showed that the application of the wastewater recycling method is able to convert all wastewater into clean water that can be used for the production process, so it does not pollute the environment. This is evident that in the process all wastewater is put into a wastewater treatment plant which is then treated again at the WTP and the treated water from the WTP is reused as process water. The application of the wastewater recycling method conducted by PT CHN can also be economically profitable, namely by being able to reduce the use of Jababeka's WTP water by 77,5\%, thereby being able to save on the cost of water purchase expenses of Rp 99.187.652 / month.

Keywords: : effectiveness, efficiency, recycling, environment, economy

\section{PENDAHULUAN}

Pengurangan limbah merupakan salah satu upaya penghematan yang menjadikan perusahaan semakin kompetitif untuk menghadapi persaingan bisnis. Seiring dengan semakin meningkatnya kepedulian akan kelestarian lingkungan, beberapa perusahaan mengupayakan pengurangan air limbah melalui perancangan proses kegiatan produksi yang lebih efektif dan efisien. Proses produksi dalam suatu industri membutuhkan air dengan syarat tertentu. Apabila air yang digunakan untuk proses industri ini kualitasnya berada di bawah standar, maka dampak yang dihasilkan adalah cepat rusaknya peralatan mesin seperti nozzel dan sistem perpipaan. Oleh karena itu diperlukan teknologi pengolahan air yang dapat menjadikan kualitas air limbah setara dengan air bersih (Yudo dan Nugroho, 2019).

Meningkatnya efisiensi produksi akan mengurangi materi yang terbuang yang diikuti dengan menurunnya biaya produksi dan dampak lingkungan. Manajemen bisnis yang menggabungkan keunggulan 
keterkaitan efisiensi lingkungan dan efisiensi ekonomi disebut eko-efisiensi (Soemarwoto, 2004).

Eko-efisiensi merupakan strategi yang bertujuan untuk menjaga keselarasan antara penggunaan sumber daya yang digunakan (ekonomi) dan polutan yang dikeluarkan (ekologi) dari kegiatan ekonomi (Levidow et al, 2015). Pendekatan eko-efisiensi ini dapat meminimalisasi volume air limbah dengan mencegah terbentuknya air limbah dalam jumlah besar, hal ini adalah tujuan proses produksi bersih (cleaner production). Inti dari cleaner production adalah untuk pencegahan, pengurangan sampai penghilangan proses pembentukan air limbah dan bahan pencemar pada serangkaian proses yang dilalui dengan memberlakukan kebijakan pencegahan terbentuknya air limbah, penerapan teknologi bersih dan ramah lingkungan, serta perubahan strategi mendasar dalam proses manajemen (Berkel, 2007).

Menurut Hukum Termodinamika ke-2, semua kegiatan yang berkaitan dengan energi dan panas akan meningkatkan entropi, termasuk kegiatan industri, yaitu menyebabkan adanya ketidakteraturan. Bentuk kenaikan entropi salah satunya adalah pencemaran lingkungan. Berdasarkan hukum ini, industri pasti melepaskan zat pencemar ke dalam lingkungan, karena zero emission dalam arti harfiah adalah mustahil. Pencemaran tidak dapat dihilangkan secara langsung, namun pencemaran itu dapat direduksi sampai seminimal mungkin (Soemantojo, 1997).

Perkembangan pesat peradaban manusia dalam ilmu pengetahuan dan teknologi telah mengubah berbagai dimensi kehidupan manusia dan lingkungannya. Penerapan ilmu pengetahuan dan teknologi (IPTEK) serta meningkatnya daya beli masyarakat dapat mendorong tumbuhnya berbagai sektor industri di Indonesia, salah satunya adalah berdirinya PT Chemco harapan Nusantara sebagai suatu bentuk industri manufaktur (Zulkifli, 2014).

PT. Chemco Harapan Nusantara (PT CHN) merupakan salah satu perusahaan manufaktur di Indonesia yang telah memproduksi komponen "Brake System \& Automotive Parts" untuk dipasok ke berbagai perusahaan otomotif jenis roda dua dan roda empat. PT CHN telah menerapkan metode daur ulang air limbah dalam penggunaan air untuk proses produksinya sejak tahun 2004. Hal tersebut dilakukan mengingat jumlah kebutuhan air bersih di PT CHN sangat banyak yaitu $10.450 \mathrm{~m}^{3} /$ bulan dan juga banyaknya air limbah yang dihasilkan. Dari penerapan metode tersebut, diharapkan mampu menurunkan atau bahkan menghilangkan air limbah dan juga mampu menghemat pengeluaran biaya untuk pembelian air bersih. Oleh sebab itu, perlu dilakukan penelitian mengenai analisis eko-efisiensi daur ulang air limbah di PT CHN.
Perumusan masalah dalam artikel ini adalah:

1. Bagaimana keuntungan bagi lingkungan yang diperoleh PT CHN dari penerapan metode daur ulang air limbah?

2. Bagaimana penerapan metode daur ulang air limbah dapat menghasilkan penghematan secara ekonomi?

Tujuan dari penelitian ini adalah untuk menerapkan metode daur ulang air limbah pada PT CHN sehingga dapat mengurangi dampak buruk bagi lingkungan akibat pembuangan air limbah dan menghasilkan penghematan secara ekonomi terutama pada saat Pandemi Covid19 ini.

\section{KAJIAN PUSTAKA DAN PERUMUSAN HIPOTESIS}

\section{A. Daur Ulang air limbah}

Seiring dengan peningkatan jumlah penduduk yang sangat pesat khususnya di daerah kawasan industri dan perkotaan. Perkembangan industri yang pesat, pencemaran air tanah maupun air permukaan, distribusi sumber air, pencemaran air tanah maupun air permukaan, serta konsumsi penggunaan air yang tidak merata telah menyebabkan ketidakseimbangan antara jumlah persediaan dan kebutuhan air bersih. Untuk mengatasi permasalahan tersebut, perlu adanya inovasi baru dalam proses penyediaan sumber air baku. Salah satu alternatif yang telah diterapkan di beberapa negara di dunia adalah dengan menerapkan daur ulang air limbah. Metode daur ulang air limbah secara umum menggunakan teknik pengolahan air limbah dan pengolahan air bersih. Dalam menerapkan metode daur ulang air limbah diperlukan beberapa tingkat proses pengolahan agar dapat mencapai kualitas air dengan kondisi tertentu sesuai dengan rencana penggunaannya (Said, 2006). Penggunaan daur ulang air limbah dikategorikan menjadi beberapa kelompok seperti yang disajikan pada Tabel 1 sebagai berikut.

Tabel 1. Kategori Penggunaan Daur Ulang Air Limbah

\begin{tabular}{|c|c|c|c|}
\hline No. & $\begin{array}{l}\text { Kegunaan air } \\
\text { limbah hasil daur } \\
\text { ulang }\end{array}$ & No. & $\begin{array}{l}\text { Kegunaan air limbah hasil } \\
\text { daur ulang }\end{array}$ \\
\hline 1. & $\begin{array}{ll}\text { Irigasi pertanian: } \\
\checkmark & \text { Pembibitan } \\
& \text { tanaman } \\
\checkmark & \text { Produksi } \\
& \text { pertanian } \\
\end{array}$ & 4 & $\begin{array}{l}\text { Fungsi lingkungan dan } \\
\quad \text { rekreasi: } \\
\checkmark \quad \text { Perikanan } \\
\text { Pengisi danau/ kolam }\end{array}$ \\
\hline 2 & \begin{tabular}{ll}
\multicolumn{2}{l}{ Irigasi landscape: } \\
$\checkmark$ & Lapangan golf \\
$\checkmark$ & Jalan raya \\
$\checkmark$ & Perumahan \\
$\checkmark$ & Taman \\
\end{tabular} & 5 & $\begin{array}{l}\text { Recharge air tanah: } \\
\checkmark \quad \text { Kontrol intrusi air } \\
\quad \text { laut } \\
\text { Pengisian air tanah }\end{array}$ \\
\hline 3 & $\begin{array}{ll}\text { Proses industri: } \\
\checkmark & \text { Umpan boiler } \\
\checkmark & \text { Pendingin } \\
\checkmark & \text { Umpan boiler } \\
\checkmark & \text { Pekerjaan } \\
& \text { konstruksi } \\
\checkmark & \text { Air proses } \\
\end{array}$ & 6 & $\begin{array}{l}\text { Keperluan umum: } \\
\checkmark \quad \text { Air bilas toilet } \\
\text { Air pemadam kebakaran }\end{array}$ \\
\hline
\end{tabular}

(Sumber: Yudo dan Nugroho, 2019) 
Limbah adalah materi yang terbuang dalam proses produksi dan tidak berakhir dalam produk. Air limbah (waste water) adalah kotoran cair yang dihasilkan dari aktivitas masyarakat, kegiatan rumah tangga dan juga yang berasal dari kegiatan industri, air permukaan, air tanah, serta buangan lainnya (Junaidi dan Hatmanto, 2016). Limbah berdasarkan sumber pencemarnya merupakan kombinasi air buangan dari instansi perusahaan, kegiatan rumah tangga (permukiman), pertokoan, dan kegiatan industri yang bercampur dengan air permukaan, air tanah ataupun air hujan (Metcalf dan Eddy, 2003).

Limbah cair yaitu air buangan yang dihasilkan dari kegiatan industri yang merupakan produk samping dari hasil utama suatu proses produksi yang dapat berkontribusi mencemari lingkungan. Dampak negatif dari limbah cair adalah sebagai berikut (Coffelt and William, 2009):

a. Sebagai pembawa penyakit sehingga dapat membahayakan kesehatan manusia.

b. Menyebabkan rusaknya bangunan, benda, tanaman dan peternakan sehingga akan merugikan segi ekonomi.

c. Menyebabkan kerusakan ekosistem air atau menyebabkan kematian organisme air seperti ikan ataupun tanaman air.

d. Menghasilkan bau tidak sedap dan merusak pemandangan terutama di daerah hilir sungai yang merupakan tempat rekreasi sehingga akan merusak keindahan (estetika).

e. Tingginya biaya perawatan dan pembuangan dari air limbah yang berbahaya dan beracun untuk memenuhi pedoman peraturan.

Berdasarkan pertimbangan di atas, harus diperhatikan dampak negatif yang dapat ditimbulkan oleh adanya pembangunan industri sebelum industri tersebut mulai beroperasi. Sehingga perlu dikaji dampaknya jika kegiatan industri dibangun, agar segera ditetapkan keputusan perlu atau tidaknya disediakan bangunan pengolah air limbah serta teknologi pengolahan air limbah dan teknologi pengolahan air bersih yang akan digunakan.

\section{B. Dampak Limbah Cair Industri Terhadap Lingkungan}

Air limbah industri terdiri dari beberapa jenis bahan pencemar baik bahan organik maupun anorganik. Bahan organik dan anorganik tersebut terdiri dari (Tejokusumo, 2007):

1. Senyawa organik berupa zat warna yang berasal dari industri penyamakan kulit dan industri cat, beberapa pelarut organik,

2. Garam anorganik berupa magnesium klorida $\left(\mathrm{MgCl}_{2}\right)$ dan magnesium sulfat $\left(\mathrm{MgSO}_{4}\right)$ yang dihasilkan dari pabrik pupuk, pabrik kertas kegiatan pertambangan, dll.

3. Asam anorganik berupa asam sulfat $\left(\mathrm{H}_{2} \mathrm{SO}_{4}\right)$ yang berasal dari industri pengolah bijih logam dan bahan bakar fosil yang mengandung kotoran berupa ikatan belerang.

4. Logam berat berupa timbal, air raksa (merkuri), kadmium dan krom yang berasal dari industri pertambangan, zat warna, baterai, penyepuhan logam, cat, dll.

Bahan organik dan anorganik tersebut jika masuk ke perairan baik air permukaan maupun air tanah akan menyebabkan tercemarnya air yang dapat membahayakan makhluk hidup pengguna air tersebut, termasuk manusia. Untuk memastikan konsumsi yang aman oleh makhluk hidup, investigasi lebih lanjut diperlukan untuk memeriksa akumulasi adanya berat logam pada hewan mengikuti dampak negatif jika dikonsumsi jangka panjang (Du et al, 2020).

\section{METODE PENELITIAN}

\section{A. Pendekatan Penelitian}

Pendekatan yang digunakan dalam penelitian ini adalah menggunakan pendekatan kuantitatif yaitu dengan menekankan analisis data numerikal (angka) yang diolah dengan metode statistika. Data primer dan sekunder diolah secara kuantitatif sehingga diperoleh kesimpulan yang menjawab rumusan masalah penelitian ini

\section{B. Desain Penelitian}

Desain penelitian akan mengarahkan proses penelitian sesuai tujuan yang ingin dicapai dan akan menjadi alur pemikiran penelitian. Desain penelitian ini dapat dilihat pada Gambar 1 sebagai berikut:

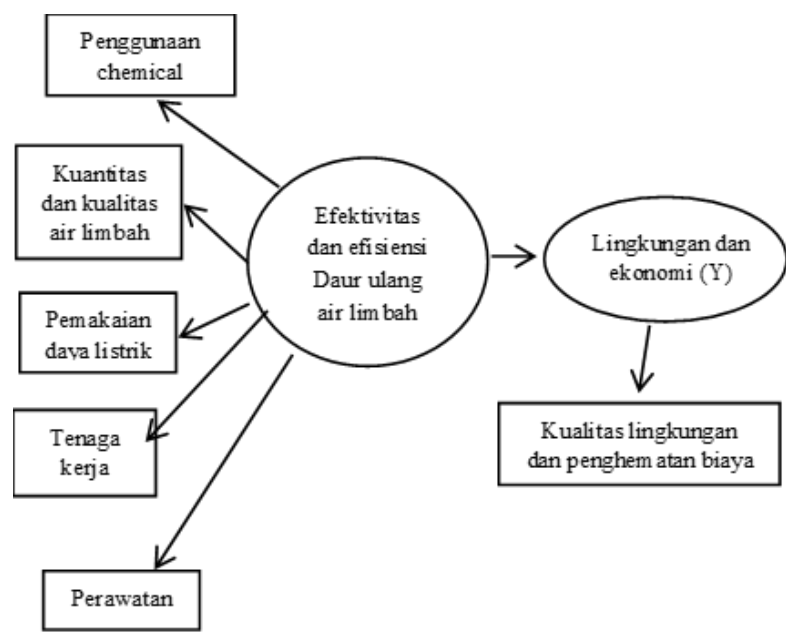

Gambar 1. Desain Penelitian

\section{Variabel Penelitian}

Variabel bebas: efektivitas dan efisiensi daur ulang air limbah $(\mathrm{X})$.

Efektivitas adalah ukuran sejauh mana suatu tujuan yang telah ditentukan tercapai sesuai dengan apa yang diharapkan. Sedangkan efisiensi adalah penggunaan sumber daya air secara minimum guna 
pencapaian hasil yang optimum. Daur ulang air limbah merupakan suatu rangkaian proses untuk mengolah air limbah menjadi air bersih yang dapat digunakan kembali untuk kegiatan semula. Dasar utama efektivitas dan efisiensi daur ulang air limbah adalah kinerja dari proses penerapan metode daur ulang air limbah baik dari tenaga kerjanya, ketepatan penggunaan chemical, kualitas dan kuantitas air limbah, perawatan (maintenance), serta pemakaian daya listrik yang digunakan.

Variabel terikat: lingkungan dan ekonomi (Y)

Lingkungan adalah kombinasi antara faktor fisik yang mencakup sumber daya alam seperti air, energi surya, tanah, mineral, serta flora dan fauna yang tumbuh di atas tanah maupun di dalam lautan, dengan objek yang mencakup produk ciptaan manusia seperti kebijakan penggunaan sumber daya alam tersebut. Lingkungan tersebut dapat rusak jika terjadi pencemaran lingkungan yang serius seperti halnya pencemaran akibat limbah cair yang di buang ke lingkungan tanpa diolah terlebih dahulu. Sedangkan ekonomi merupakan salah satu ilmu sosial yang mempelajari aktivitas manusia yang berhubungan dengan produksi, distribusi, dan konsumsi terhadap barang dan jasa.

\section{Metode Pengumpulan Data}

\section{Metode Survei}

Metode ini dilakukan dengan berkomunikasi langsung antara peneliti dengan pembimbing lapangan, karyawan atau petugas berwenang lainnya yang bersangkutan mengenai daur ulang air limbah di PT CHN.

\section{Metode Observasi}

Metode ini dilakukan dengan mengamati dan mencatat secara sistematis terhadap gejala serta fakta yang dihadapi dan terjadi selama berada di lapangan.

\section{E. Jenis Data Penelitian}

\section{Data Sekunder}

Data sekunder dikumpulkan dari dokumen-dokumen dan referensi- referensi yang ada. Pengumpulan data sekunder yang dibutuhkan dalam penelitian adalah :

1. Data literatur, jurnal, makalah dan laporan penelitian terdahulu

2. Data profil perusahaan

3. Data karakteristik efluen air limbah

4. Data bahan kimia yang digunakan serta kebutuhan rata-rata pemakaian

5. Data daftar harga bahan kimia dan harga keperluan pendukung lainnya

6. Data daftar bahan/ material yang perlu dilakukan perawatan atau penggantian

7. Data penerapan metode daur ulang air limbah yang sudah ada
8. Data Instalasi Pengolahan Limbah Cair yang sudah ada

9. Data Instalasi Pengolahan Air Bersih yang sudah ada

10. Data pemakaian listrik dalam proses pengolahan air limbah dan air bersih

11. Data spesifikasi desain unit pengolah air limbah dan air bersih.

\section{Data Primer}

Data primer dikumpulkan di dalam lokasi dengan melakukan pengamatan langsung atas kinerja unit pengolahan limbah cair dan air bersih di PT CHN dan wawancara dengan para pekerja. Data primer yang dibutuhkan diantara-Nya:

1. Data proses produksi pemakai air bersih dan kebutuhan air bersih

2. Data kualitas influen air limbah dan kualitas air olahan dari unit pengolahan air bersih

3. Data proses pengolahan air limbah dan pengolahan air bersih

\section{F. Teknik Analisis Data}

Beberapa tahapan analisis yang telah dilakukan oleh peneliti yaitu:

1. Data coding

Peneliti melakukan penyusunan secara sistematis data mentah yang diperoleh saat wawancara dan observasi ke dalam bentuk yang mudah dibaca oleh mesin pengolah yaitu komputer.

2. Data entering Peneliti melakukan proses pemindahan data yang telah diubah menjadi kode ke dalam komputer.

3. Data cleaning

Peneliti memastikan bahwa seluruh data yang dimasukan ke dalam mesin pengolah data sudah sesuai dengan yang sebenarnya.

4. Data display

Peneliti melakukan penyajian data dalam berbagai macam bentuk seperti grafik tabel dan lain sebagainya.

5. Data analizing

Peneliti melakukan proses pengolahan data lanjutan untuk melihat bagaimana menginterpretasikan data, kemudian menganalisis data dari hasil yang sudah ada pada tahap pengolahan data.

Efisiensi penggunaan dana dapat dievaluasi dengan menggunakan persamaan sebagai berikut (Soeparman dan Suparmin, 2001):

Efisiensi $(x)=\frac{\text { inlet cost }- \text { outlet cost }}{\text { inlet cost }} \times 100 \%$

Persamaan (1) merupakan persamaan yang digunakan untuk menentukan efisiensi. Adapun tingkat efisiensi dikelompokkan sebagai berikut (Soeparman dan Suparmin, 2001): 
- $\quad$ Tidak efisien : $\mathrm{x} \leq 20 \%$

- Kurang efisien : $20 \%<\mathrm{x} \leq 40$

- Cukup efisien : $40 \%<\mathrm{x} \leq 60 \%$

- Efisien : $60 \%<\mathrm{x} \leq 80 \%$

- $\quad$ Sangat efisien : $x>80 \%$

\section{G. Tahapan Penelitian}

Penelitian ini terdiri dari 3 tahap yaitu tahap persiapan, tahap pelaksanaan dan tahap penyusunan laporan.

\section{Tahap Persiapan}

Peneliti mengumpulkan referensi dan studi literatur terhadap obyek penelitian dan konsep dasar sistem pengolahan limbah cair industri dan pengolahan air bersih. Kemudian dilanjutkan dengan proses administrasi sampai diperoleh persetujuan pelaksanaan penelitian pada obyek tersebut.

\section{Tahap Pelaksanaan}

Dalam tahap ini, peneliti melakukan kajian pustaka, observasi, wawancara, pengumpulan data - data pendukung serta melakukan pekerjaan - pekerjaan yang terdapat di tempat penelitian. Pelaksanaan penelitian dilakukan selama 4 (empat) jam yaitu antara jam 13:00 - 17:00 WIB. Sedangkan pada jam 08:00 - 12:20 WIB Peneliti melakukan pekerjaan sesuai departemennya yatu PPPC (Process Production Planning Control).

\section{Tahap Penyusunan Laporan}

Dalam tahap ini, peneliti melakukan penyusunan laporan penelitian berdasarkan data dan hasil penelitian yang telah dilakukan.

\section{ANALISIS DAN RANCANGAN}

\section{Hasil Penelitian dan Pembahasan}

\section{A. Kualitas Dan Kuantitas Influen Air Limbah}

Kualitas dan kuantitas air limbah dari semua proses produksi yang memakai air di PT Chemco Harapan Nusantara tidaklah sama untuk setiap harinya, hal tersebut tergantung dari kegiatan produksi. Jika permintaan dari customer naik, maka kegiatan produksi akan naik yang menyebabkan limbah cair yang di hasilkan juga ikut naik baik dari kualitas maupun kuantitas. Oleh karena itu, debit air limbah ditentukan menggunakan debit rata-rata sehingga diperoleh debit air limbah sebesar 14,5 m³/jam yang diperoleh dari:

Debit per bulan $=10.450 \mathrm{~m}^{3}$, sehingga debit rata-rata perjam $=10.450 / 30$ hari/ 24 jam $=14,5 \mathrm{~m}^{3} / \mathrm{jam}$. Sedangkan untuk parameter kualitas air limbah yang digunakan oleh PT CHN yaitu konduktivitas. Adapun konduktivitas air limbah yang dihasilkan yaitu sebesar $2000 \mu \mathrm{S} / \mathrm{cm}$.

\section{B. Proses Penerapan Metode Daur Ulang Air Limbah}

Proses penerapan metode daur ulang air limbah di PT Chemco Harapan Nusantara dilakukan dengan cara menggabungkan dua unit pengolahan air yaitu pengolahan air limbah (Wastewater Treatment Plant/WWTP) dan pengolahan air bersih (Water Treatment Plant/WTP). Kemudian air bersih dari hasil olahan WTP didistribusikan ke masing-masing proses produksi, sesuai dengan kualitas dan kuantitas air yang dibutuhkan. Adapun alur proses penerapan metode daur ulang limbah disajikan pada Gambar 2 sebagai berikut:

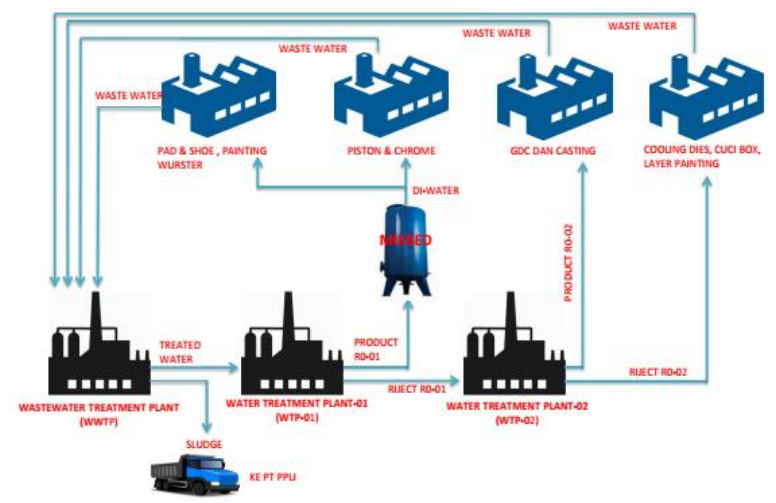

Gambar 2. Alur Proses Penerapan Metode Daur Ulang Air Limbah

\section{Proses Pengolahan Air Limbah}

Air limbah yang dihasilkan dari setiap proses produksi dikumpulkan di bak pengumpul (pit). Dari bak pengumpul tersebut, air limbah di pompa menuju wastewater treatment plant (WWTP) untuk diolah. Berdasarkan hasil observasi peneliti menunjukkan bahwa effluent yang dihasilkan dari WWTP telah memenuhi jaminan kualitas effluent yang telah ditentukan. Pada tahun 2002, PT Chemco Harapan Nusantara telah membangun suatu instalasi pengolahan air limbah oleh kontraktor yang berasal dari Taiwan yaitu TAI - EN Enterprises Corporation. WWTP tersebut dibangun dengan kapasitas $20 \mathrm{~m}^{3} / \mathrm{jam}$ dan dengan jaminan kualitas effluent yang disajikan pada Tabel 2 sebagai berikut:

Tabel 2. Jaminan kualitas effluent

\begin{tabular}{|c|c|c|}
\hline Parameter & Satuan & Nilai \\
\hline $\mathrm{pH}$ & & $6-9$ \\
\hline BOD $_{5}$ & $\mathrm{mg} / \mathrm{l}$ & $<50$ \\
\hline $\mathrm{COD}$ & $\mathrm{mg} / \mathrm{l}$ & $<100$ \\
\hline $\mathrm{SS}$ & $\mathrm{mg} / \mathrm{l}$ & $<5$ \\
\hline Oil dan Grease & $\mathrm{mg} / \mathrm{l}$ & $<0,1$ \\
\hline $\mathrm{CN}$ & $\mathrm{mg} / \mathrm{l}$ & $<0,5$ \\
\hline $\mathrm{T}-\mathrm{Cr}$ & $\mathrm{mg} / \mathrm{l}$ & $<0,1$ \\
\hline $\mathrm{Cr}+6$ & $\mathrm{mg} / \mathrm{l}$ & $<5$ \\
\hline $\mathrm{Zn}$ & $\mathrm{mg} / \mathrm{l}$ & $<0,5$ \\
\hline $\mathrm{Ni}$ & $\mathrm{mg} / \mathrm{l}$ & $<$ \\
\hline
\end{tabular}




\section{Proses pengolahan air bersih}

Dalam mengolah air limbah yang cukup tinggi, PT Chemco Harapan Nusantara menghasilkan air limbah (effluent) WWTP yang mempunyai kualitas sesuai dengan standar baku mutu. Pada awalnya, effluent WWTP tersebut dibuang ke WWTP Jababeka. Mengingat bahwa harga air bersih

Proses pengolahan air effluent dari WWTP ini terdiri dari beberapa rangkaian proses di Water Treatment semakin lama semakin tinggi, serta adanya pungutan biaya pembuangan air limbah effluent ke WWTP kawasan industri Jababeka, maka PT Chemco Harapan Nusantara bersama kontraktor PT. Tirtakreasi Amrita pada tahun 2004 membangun instalasi pengolahan air bersih berkapasitas 15 $\mathrm{m}^{3} / \mathrm{jam}$.

Plant 1 dan Water Treatment Plant 2 yang disajikan pada Gambar 3 dan Gambar 4 sebagai berikut:

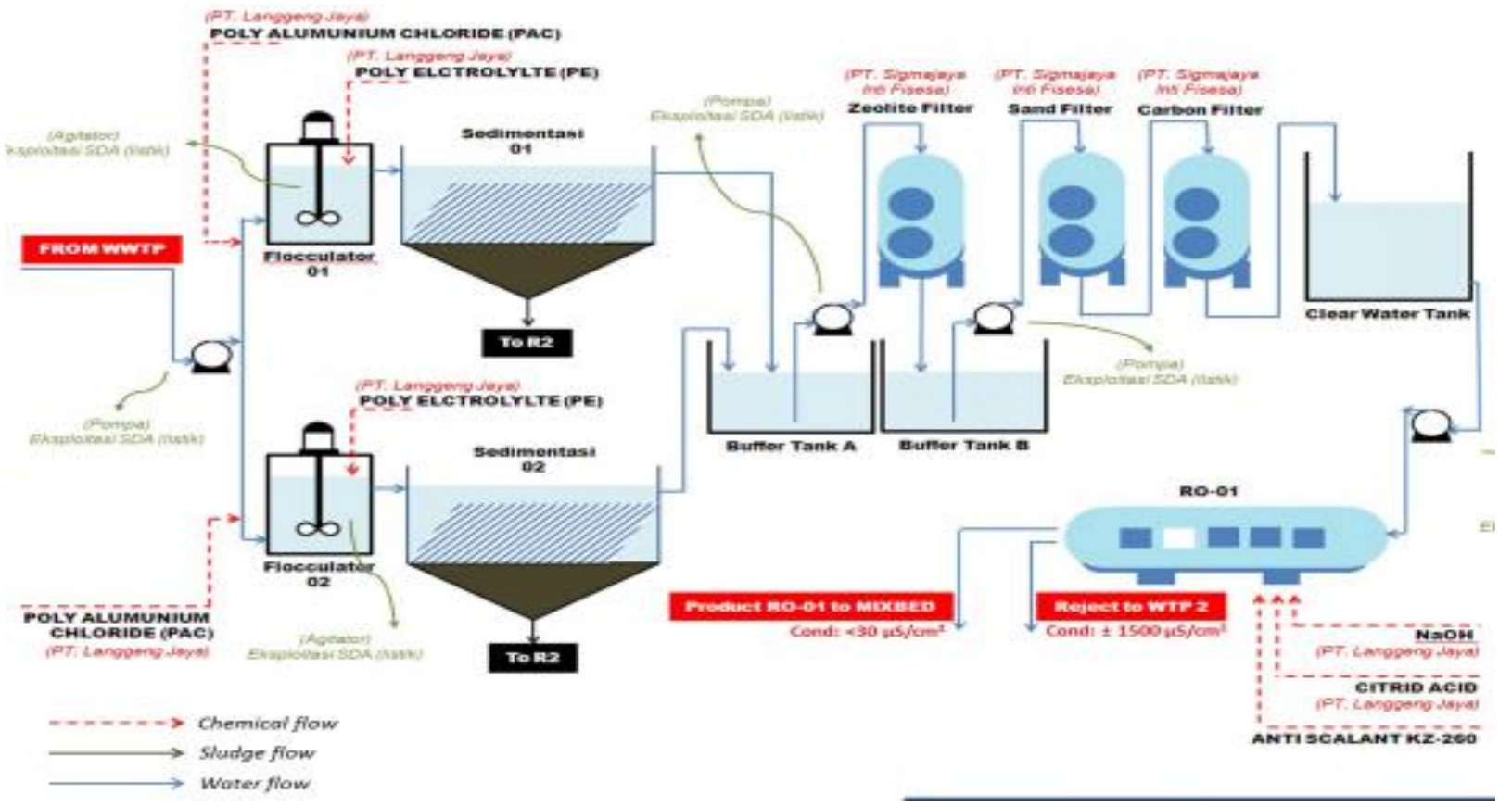

Gambar 3. Alur Proses Water Treatment Plant 1

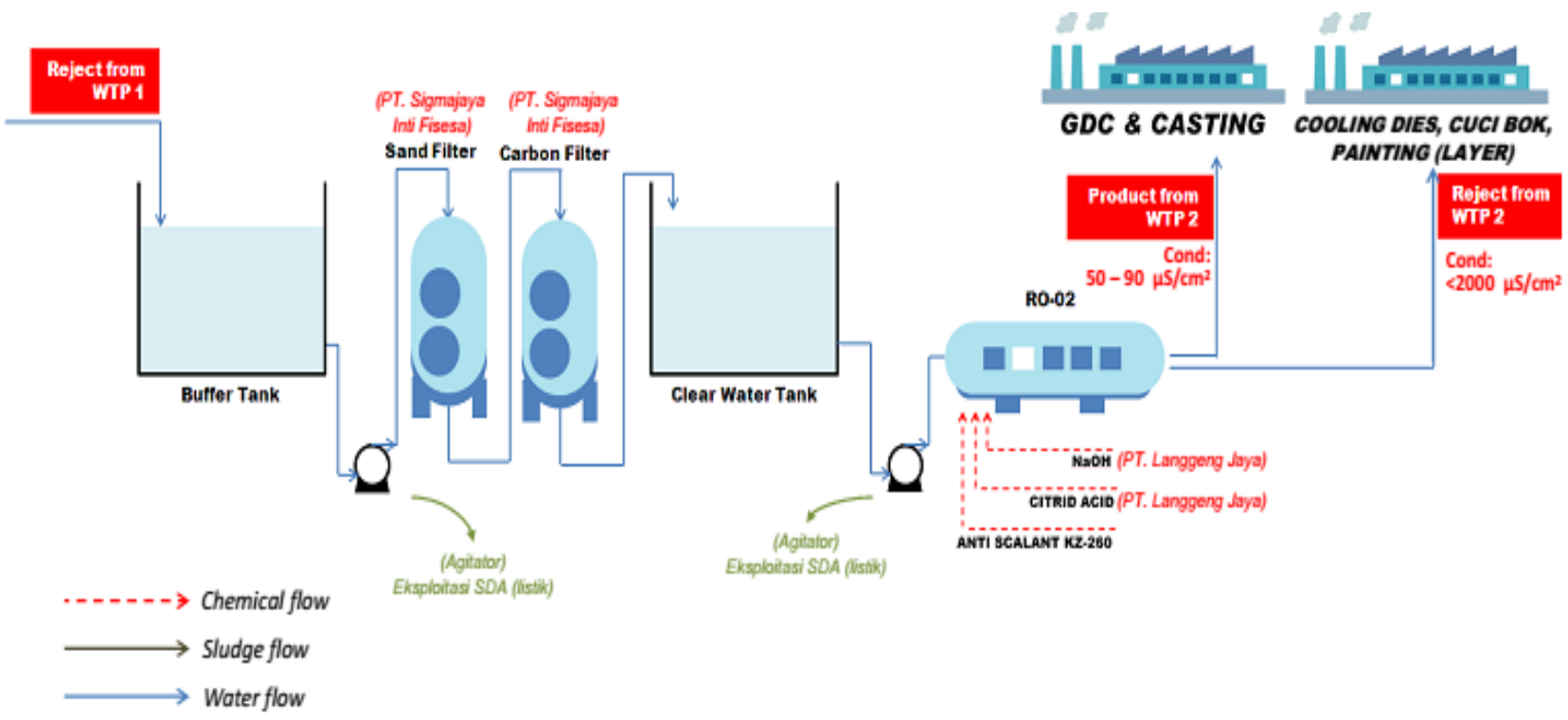

Gambar 4. Alur Proses Water Treatment Plant 2 


\section{E. Pemanfaatan Air Olahan WTP}

Dari seluruh rangkaian proses penerapan metode daur ulang air limbah yang dilakukan oleh PT Chemco Harapan Nusantara, maka dihasilkan air bersih yang dapat digunakan kembali sebagai process water. Penggunaan air olahan tersebut disesuaikan dengan kualitas air yang dibutuhkan dalam setiap proses produksi. Sehingga tidak ada air yang dibuang begitu saja ke lingkungan mengingat bahwa harga air bersih semakin mahal serta air merupakan komponen ekosistem yang sangat penting bagi kehidupan manusia.

Pemanfaatan air olahan WTP dapat dilihat pada Tabel 3 sebagai berikut:

Tabel 3. Pemanfaatan air olahan WTP

\begin{tabular}{|c|c|c|c|c|c|}
\hline \multirow{2}{*}{ No } & \multirow{2}{*}{$\begin{array}{c}\text { Proses } \\
\text { Produksi }\end{array}$} & \multirow{2}{*}{$\begin{array}{c}\text { Kebutu } \\
\text { han } \\
\text { air } \\
\left(\mathrm{m}^{3} / \mathrm{bln}\right. \\
)\end{array}$} & \multicolumn{2}{|c|}{$\begin{array}{c}\text { Pemenuhan } \\
\text { kebutuhan air ( } \\
\mathrm{m}^{3} / \mathrm{bln} \text { ) }\end{array}$} & \multirow{2}{*}{ Ket. } \\
\hline & & & $\begin{array}{c}\text { WTP } \\
\text { Jababek } \\
\text { a } \\
\end{array}$ & $\begin{array}{c}\text { WTP } \\
\text { Chemco }\end{array}$ & \\
\hline 1 & $\begin{array}{l}\text { Treatment } \\
\text { pad comp } \\
\text { dan body } \\
\text { shoe }\end{array}$ & 1.150 & 500 & 650 & $\begin{array}{l}\text { Air olahan } \\
\text { mixed-bed }\end{array}$ \\
\hline 2 & $\begin{array}{l}\text { Pretreatment } \\
\text { painting } \\
\text { wurster }\end{array}$ & $\begin{array}{l}2.2 \\
25\end{array}$ & 1.100 & 1.125 & $\begin{array}{l}\text { Air olahan } \\
\text { mixed-bed }\end{array}$ \\
\hline 3 & $\begin{array}{l}\text { Pelapisan } \\
\text { chrome }\end{array}$ & 375 & 0 & 375 & $\begin{array}{l}\text { Air olahan } \\
\text { mixed-bed }\end{array}$ \\
\hline 4 & $\begin{array}{l}\text { Treatment } \\
\text { piston }\end{array}$ & $\begin{array}{l}1.6 \\
50\end{array}$ & 0 & 1.650 & $\begin{array}{l}\text { Air olahan } \\
\text { mixed-bed }\end{array}$ \\
\hline 5 & $\begin{array}{c}\text { Stok air } \\
\text { untuk } \\
\text { regenerasi \& } \\
\text { backwash } \\
\text { mixed-bed }\end{array}$ & 520 & 0 & 520 & $\begin{array}{l}\text { Air olahan } \\
\text { mixed-bed }\end{array}$ \\
\hline 6 & $\begin{array}{c}\text { Spraying dies } \\
\text { dan } \\
\text { quenching } \\
\text { pada proses } \\
\text { GDC \& } \\
\text { Casting } \\
\end{array}$ & $\begin{array}{c}201 \\
6\end{array}$ & 0 & 2016 & $\begin{array}{l}\text { Air produk/ } \\
\text { permeate } \\
\text { dari RO-02 }\end{array}$ \\
\hline 7 & Proses Burrel & 375 & 375 & 0 & \\
\hline 8 & $\begin{array}{c}\text { Proses } \\
\text { Machining }\end{array}$ & 375 & 375 & 0 & \\
\hline 9 & $\begin{array}{c}\text { Cooling dies } \\
\text { pada proses } \\
\text { GDC \& } \\
\text { Casting }\end{array}$ & $\begin{array}{l}1.2 \\
34\end{array}$ & 0 & 1.234 & $\begin{array}{c}\text { Air reject } \\
\text { dari } \mathrm{RO}-02\end{array}$ \\
\hline 10 & Cuci bok & $\begin{array}{c}187 \\
, 5 \\
\end{array}$ & 0 & 187,5 & $\begin{array}{c}\text { Air reject } \\
\text { dari RO-02 }\end{array}$ \\
\hline 11 & $\begin{array}{l}\text { Layer dalam } \\
\text { proses spray } \\
\text { booth }\end{array}$ & $\begin{array}{c}342 \\
, 5\end{array}$ & 0 & 342,5 & $\begin{array}{c}\text { Air reject } \\
\text { dari } \mathrm{RO}-02\end{array}$ \\
\hline & JMLAH & $\begin{array}{l}10 . \\
450\end{array}$ & 2.350 & 8.100 & \\
\hline
\end{tabular}

\section{F. Efektivitas dari Segi Lingkungan}

Berdasarkan Tabel 3 maka peneliti dapat menganalisis dan menghitung efektivitas penerapan metode daur ulang air limbah di PT Chemco Harapan Nusantara dari segi lingkungan. Adapun perhitungannya adalah sebagai berikut:

Diketahui :

Total kebutuhan air bersih $=10.450 \mathrm{~m}^{3} /$ bulan

$\checkmark$ Debit air limbah yang masuk ke WWTP $=8.100 \mathrm{~m}^{3} /$ bulan

Debit air limbah yang tidak masuk ke $\mathrm{WWTP}=2.350 \mathrm{~m}^{3} /$ bulan

Penentuan debit air limbah diperoleh dari besarnya pemakaian air bersih dengan memperhitungkan faktor kehilangan air (Metcalf and Eddy, 2003), dimana besarnya debit air limbah sama dengan $80 \%$ dari konsumsi air bersih. Maka dapat di buktikan bahwa semua air limbah yang di hasilkan oleh proses-proses produksi pengguna air bersih di PT Chemco Harapan Nusantara masuk ke WWTP dan pengolahan lain tanpa ada yang dibuang ke lingkungan.

Persentase Debit air limbah yang masuk ke WWTP
$8.100 \mathrm{~m}^{3} /$ bulan $=\frac{\mathrm{y}}{100} \times 10.450 \mathrm{~m}^{3} /$ bulan
$8.100 \mathrm{~m}^{3} /$ bulan
$=104,5 \mathrm{y} \mathrm{m}^{3} /$ bulan

$$
\text { y }=77,51 \%
$$

Persentase Debit air limbah yang tidak masuk ke WWTP ( masuk ke pengolahan lain)

$$
\begin{aligned}
2.350 \mathrm{~m}^{3} / \text { bulan } & =\frac{\mathrm{y}}{100} \times 10.450 \mathrm{~m}^{3} / \text { bulan } \\
2.350 \mathrm{~m}^{3} / \text { bulan } & =104,5 \mathrm{y} \mathrm{m}^{3} / \text { bulan } \\
\mathrm{y} & =22,49 \%
\end{aligned}
$$

Jadi, total persentase debit air limbah yaitu 77,51\% + $22,49 \%=100 \%$

Dengan menerapkan metode daur ulang air limbah, PT Chemco Harapan Nusantara selain mampu mengolah air limbah tanpa ada yang dibuang ke lingkungan juga mampu mengubah kualitas air limbah yang buruk menjadi air bersih yang berkualitas sangat baik. Konduktivitas air limbah yang dihasilkan dari metode daur ulang dapat dilihat pada Gambar 5 sebagai berikut:

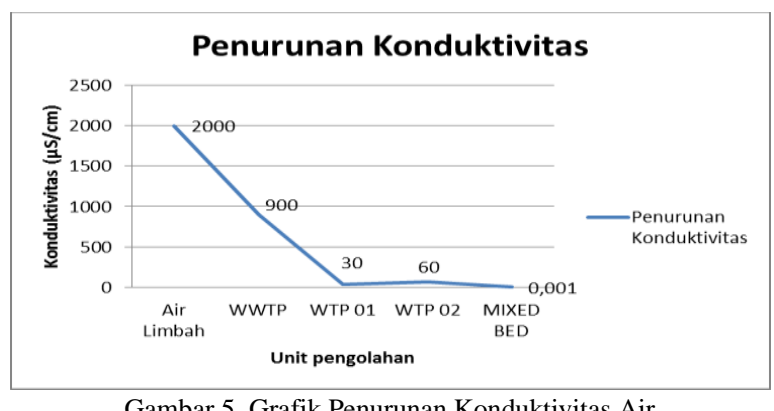

Gambar 5. Grafik Penurunan Konduktivitas Air

Berdasarkan grafik di atas menunjukkan bahwa konduktivitas air limbah selama berada di unit pengolahan akan terus mengalami penurunan. Hal ini menunjukkan bahwa selama proses pengolahan air limbah terjadi penurunan konsentrasi ion terlarut dari 
air limbah selama proses pengolahan hingga menuju reaktor fixed bed. Sehingga dapat menyebabkan penurunan daya hantar listrik air yang dihasilkan (Khairunnas, 2018).

\section{G. Biaya Pengolahan Air dan Penghematan Pengeluaran}

Dalam dunia usaha, masalah efisiensi pengeluaran biaya tentunya menjadi hal yang paling di perhitungkan demi mendapatkan keuntungan yang besar. Oleh sebab itu, maka peneliti melakukan analisis dan perhitungan dari aspek ekonomi mengenai adanya penerapan metode daur ulang air limbah di PT Chemco Harapan Nusantara. Berikut perhitungan yang peneliti lakukan berdasarkan kondisi di tahun 2019:

Tabel 4. Perhitungan Biaya Pengolahan untuk Manpower

\begin{tabular}{|c|c|}
\hline \multicolumn{2}{|c|}{ A. MANPOWER } \\
\hline Salary/month (1 operator) & Rp 4.294.045,00 \\
\hline Salary/month (4 operator) & Rp 17.176.180,00 \\
\hline price/m3 air & $2.120,52$ \\
\hline
\end{tabular}

(Sumber: Hasil Olah Data Penelitian, 2018)

Tabel 5. Perhitungan Biaya Pengolahan untuk WWTP

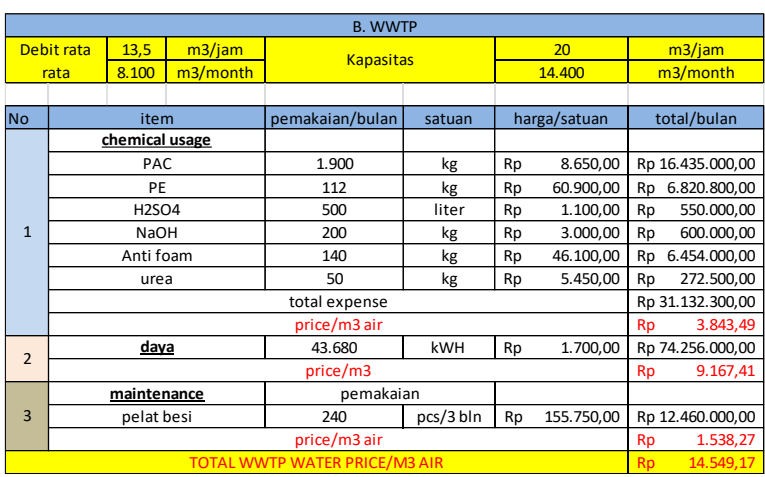

(Sumber: Hasil Olah Data Penelitian, 2018)

Tabel 6. Perhitungan Biaya Pengolahan untuk WTP-01

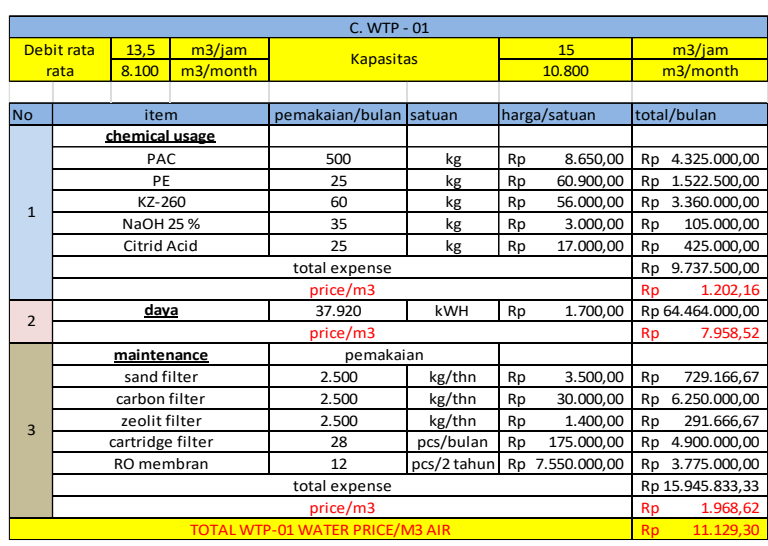

(Sumber: Hasil Olah Data Penelitian, 2018)
Tabel 7. Perhitungan Biaya Pengolahan untuk WTP-02

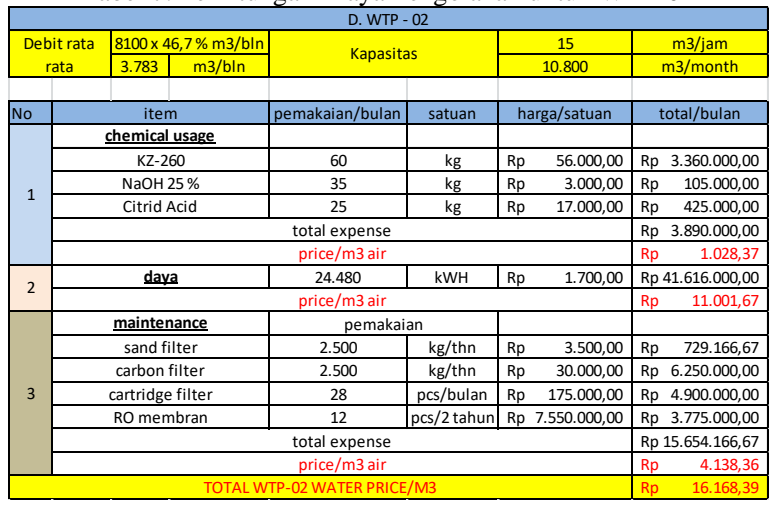

(Sumber: Hasil Olah Data Penelitian, 2018)

Tabel 8. Perhitungan Biaya Pengolahan untuk Mixed-bed

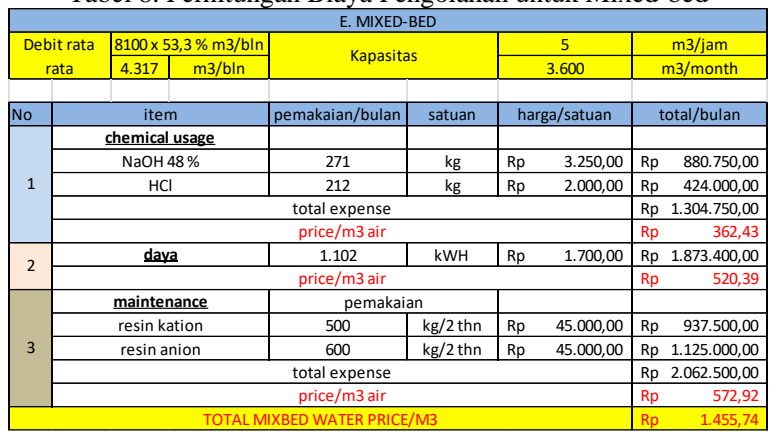

(Sumber: Hasil Olah Data Penelitian, 2018)

Tabel 9. Perhitungan Biaya Penyusutan unit WTP-01

\begin{tabular}{|c|c|c|c|c|c|c|}
\hline No & Nama peralatan & Jumlah & Harga & $\begin{array}{l}\text { Umur manfaat } \\
\text { (thn) }\end{array}$ & pen & $\begin{array}{l}\text { biaya } \\
\text { Isutan /bln }\end{array}$ \\
\hline 1 & Static mixer & 1 & Rp 2.000 .000 & 8 & \begin{tabular}{|l|l|}
8 & $R p$ \\
\end{tabular} & 20.833 \\
\hline 2 & Agitator & 4 & Rp 10.000.000 & 8 & \begin{tabular}{|l|l|}
8 & $R p$
\end{tabular} & 416.667 \\
\hline 3 & Pompa & 7 & Rp 5.959 .000 & 8 & $8 \mathrm{Rp}$ & 434.510 \\
\hline & Dosing pump & 3 & Rp 12.430 .000 & 8 & \begin{tabular}{l|l}
$8 p$ \\
$R p$
\end{tabular} & 388.438 \\
\hline \multicolumn{5}{|c|}{ Total biaya penyusutan ( depresiasi } & $\mathrm{Rp}$ & 1.260 .448 \\
\hline
\end{tabular}

(Sumber: Hasil Olah Data Penelitian, 2018)

Dari tabel hasil perhitungan di atas, maka dapat dilakukan perbandingan harga air olahan WTP PT. Chemco Harapan Nusantara dengan harga air dari WTP Jababeka. Dikarenakan air baku WTP Jababeka dari air sungai bukan air limbah, dan juga instalasi pengolahan air limbah, mixed-bed ion exchanger serta WTP-02 merupakan instalasi yang harus ada di PT Chemco, maka harga per $\mathrm{m}^{3}$ air yang dihitung dari biaya pengolahan di WTP PT Chemco yaitu hanya penjumlahan dari biaya untuk manpower, biaya pengolahan untuk WTP-01 dan biaya penyusutan WTP-01. Sehingga peneliti dapat mengetahui efisiensi penerapan metode daur ulang air limbah dari segi ekonomi seperti yang disajikan pada Tabel 10 sebagai berikut:

Tabel 10: Perbandingan Harga Air

\begin{tabular}{|c|c|c|c|}
\hline \multirow{2}{*}{ Air Bersih } & \multicolumn{2}{|c|}{ konduktivitas $(\mu \mathrm{s} / \mathrm{cm})$} & \multirow{2}{*}{ harga per m3 } \\
\cline { 2 - 3 } & air baku & air olahan & \\
\hline Air WTP Jababeka & & 300 & Rp25.650,00 \\
\hline Air WTP Chemco & 900 & $<30$ & Rp13.405,43 \\
\hline \multicolumn{2}{|c|}{ selisih } & 270 & Rp12.244,57 \\
\hline
\end{tabular}

Sumber: Hasil Olah Data Penelitian, 2018 
Jika dalam pemenuhan air proses produksi seluruhnya memakai air dari WTP Jababeka, maka dapat dihitung biaya pengeluaran sebagai berikut:

Biaya pengeluaran $=$ total kebutuhan air $\mathrm{x}$ harga air WTP Jababeka

$$
\begin{aligned}
& =10.450 \mathrm{~m}^{3} / \text { bulan } \times \operatorname{Rp} 25.650 / \mathrm{m}^{3} \\
& =\operatorname{Rp} 268.042 .500 / \text { bulan }
\end{aligned}
$$

Sedangkan dengan adanya penerapan metode daur ulang air limbah, maka dapat dihitung biaya pengeluaran sebagai berikut:

Biaya pengeluaran $=$ (total pemakaian air WTP jababeka x harga air WTP

Jababeka) + (total pemakaian air WTP Chemco x harga air WTP Chemco) + biaya penyusutan

$=\left(2350 \mathrm{~m}^{3} / \mathrm{bln} \times \mathrm{Rp} 25.650 / \mathrm{m}^{3}\right)+\left(8100 \mathrm{~m}^{3} / \mathrm{bln} \times\right.$

Rp $\left.13.405 / \mathrm{m}^{3}\right)+\operatorname{Rp} 1.260 .448 / \mathrm{bln}$

$=\operatorname{Rp} 60.277 .500 /$ bulan + Rp 107.316.900 /bulan + $\mathrm{Rp}$

$1.260 .448 /$ bulan

$=\operatorname{Rp} 168.854 .848 /$ bulan

Jadi, penghematan pengeluaran biaya untuk pemakaian air bersih yaitu pengurangan antara biaya pengeluaran jika seluruh kebutuhan air memakai air WTP Jababeka dengan jika diterapkannya metode daur ulang air limbah. Sehingga diperoleh:

Penghematan biaya pengeluaran $=\mathrm{Rp} 268.042 .500$ /bulan - Rp 168.854.848 /bulan $=\mathrm{Rp} 99.187 .652$ /bulan.

\section{KESIMPULAN DAN SARAN}

\section{A. Kesimpulan}

Berdasarkan hasil penelitian yang telah dilakukan dapat disimpulkan bahwa:

1. Penerapan metode daur ulang air limbah pada PT CHN mampu mengubah kualitas air yang sangat buruk menjadi air bersih yang berkualitas sangat baik. Selain itu, PT CHN sama sekali tidak membuang air limbah yang dapat mencemari lingkungan.

2. Penerapan metode daur ulang air limbah pada PT CHN dapat mengurangi pemakaian air WTP Jababeka sebesar $77,5 \%$. Sehingga mampu menghemat biaya pengeluaran pembelian air sebesar Rp 99.187.652 /bulan.

\section{B. Saran}

Dari pengamatan peneliti ada beberapa parameter yang perlu ditingkatkan lagi kinerjanya. Oleh karena itu peneliti memberikan saran sebagi berikut:

1. Penambahan debit influent pengolahan WWTP mengingat kapasitas pengolahan yaitu sebesar $20 \mathrm{~m}^{3} / \mathrm{jam}$, sedangkan debit influent rata-rata yang diolah hanya $13,5 \mathrm{~m}^{3} / \mathrm{jam}$. Dikarenakan air limbah merupakan $80 \%$ dari pemakaian air bersih, maka Peneliti menyarankan bahwa untuk penembahan debit influent pengolahan WWTP dapat ditambahkan dari air limbah cuci tangan dan sisa dari air wudhu. Dengan demikian, air olahan WTP akan bertambah kuantitasnya sehingga akan memperkecil lagi pembelian air bersih untuk kegiatan produksi.

2. Meningkatkan efektivitas kinerja zeolit filter, sand filter, dan karbon filter dengan melakukan perhitungan berdasarkan kriteria desain mengenai ketebalan dan ukuran media filter yang digunakan.

\section{DAFTAR PUSTAKA}

Berkel, R. V. (2007). Cleaner production and EcoEfficiency Initiatives in Western Australia 1996-2004. Journal of Cleaner production, 15, 741-755.

Coffel, T.A. dan William, C.F. (2009). Characterization and Recycling of Waste Water from Guayule Latex Extraction. Industrial and Crop Product, 29, , 648-653

https://doi.org/10.1016/j.indcrop.2008.10.004.

Du, Yongming., Wu, Q., Kong, D., Shi, Y., Huang, X., Luo, D., (2020). Accumulation and translocation of heavy metals in water hyacinth: Maximising the use of green resources to remediate sites impacted by ewaste recycling activities. Ecological Indicators., 115, 106384.

https://doi.org/10.1016/j.ecolind.2020.106384.

Junaidi dan Hatmanto, B.S.D. (2016). Analisis Teknologi Pengolahan Limbah Cair Pada Industri Tekstil (Studi Kasus Pt. Iskandar Indah Printing Textile Surakarta). Semarang: Jurnal Teknik Lingkungan Universitas Diponegoro.

Khairunnas dan Gusman, M. (2018). Analisis Pengaruh Parameter Konduktivitas, Resistivitas dan TDS Terhadap Salinitas Air Tanah Dangkal pada Kondisi Air Laut Pasang dan Air Laut Surut di Daerah Pesisir Pantai Kota Padang. Jurnal Bina Tambang, Volume 3, No. 4.

Levidow, L., Jorgensen, P. L., Nilsson, A., Skenhall, S. A., \& Assimacopoulos, D. (2015). Process Eco-Innovation: Assessing Meso-Level EcoEfficiency in Industrial Water-Service System. Journal of Cleaner production, xxx, 1-12. 8.

Metcalf and Eddy. (2003). Wastewater Engineering : Treatment, Disposal, and Reuse. Third Edition. Mcgraw Hill. Singapore.

Tejokusumo, Bambang. (2007). Skripsi: Limbah Cair Industri serta Dampaknya Terhadap Kualitas Air Tanah Dangkal di Desa Gumpang Kecamatan Kartasura. Surakarta: Jurnal Fakultas Keguruan Dan Ilmu Pendidikan. Universitas Sebelas Maret.

Soemantojo, R.W. (1997). Pengelolaan Limbah.Diktat Penyelenggaraan Pendidikan Percepatan Insinyur Program Studi Teknik 
Gas dan Petrokimia. Jakarta: Fakultas Teknik, Universitas Indonesia.

Soemarwoto, O. (2004). Ekologi, Lingkungan Hidup dan Pembangunan. Edisi Kesepuluh. Jakarta: Djambatan. 7.

Soeparman, H.M. \& Suparmin. (2001). Pembuangan Tinja dan Limbah Cair, Suatu Pengantar. Penerbit buku Kedokteran EGC, Jakarta.

Yudo, Satmoko dan Nugroho, Rudi. (2019). Uji Kinerja Instalasi Daur Ulang Air Limbah Industri Kaleng di Jakarta. Jurnal Teknologi Lingkungan Volume 20, No 2, Juli 2019. https://doi.org/10.29122/jtl.v20i2.3413

Zulkifli, A. (2014). Pengelolaan Limbah Berkelanjutan. Cetakan Pertama. Jakarta: Graha Ilmu 